\title{
PENGARUH PENDIDIKAN KESEHATAN TERHADAP PENGETAHUAN TENTANG KEPUTIHAN PADA REMAJA PUTRI DI SMA NEGERI 1 TALANG KELAPA BANYUASIN
}

\author{
Putinah $^{1}$ \\ 1.Dosen Tetap STIK Siti Khadijah \\ Email: putinahners@gmail.com
}

\begin{abstract}
ABSTRAK
Keputihan dapat di anggap sebagai salah satu alarm tubuh terutama untuk masalah reproduksi karena itu kesehatan reproduksi merupakan komponen penting bagi kesehatan wanita. Keputihan juga kerap di anggap sebagai masalah kewanitaan yang biasa-biasa saja walaupun sering dialami oleh wanita. Kesehatan reproduksi remaja adalah suatu kondisi sehat yang menyangkut sistem, fungsi, dan proses reproduksi yang dimiliki oleh remaja untuk itu remaja seringkali kekurangan informasi mengenai kesehatan reproduksi, sebab itu pemberian pendidikan kesehatan menjadi penting untuk diberikan kepada para remaja putri. Penelitian ini bertujuan untuk mengetahui pengaruh penyuluhan kesehatan terhadap pengetahuan tentang keputihan pada remaja putri di SMA Negeri 1 Talang Kelapa Banyuasin. Penelitian ini menggunakan desain pre eksperimen dengan pendekatan one group pretest posttest, sampel penelitian ini adalah remaja putri kelas $X$ dengan jumlah 33 orang, teknik pengambilan sampel yang digunakan dengan teknik random sampling yaitu systematic random sampling, instrumen dalam penelitian menggunakan kuisioner. Penelitian ini dilaksanakan pada tanggal 01-14 November tahun 2019. Hasil penelitian pengetahuan remaja putri sebelum dilakukan penyuluhan kesehatan didapatkan nilai rata-rata 51,82 dengan standar deviasi 4,11. Pengetahuan remaja putri sesudah dilakukan penyuluhan kesehatan didapatkan nila rata-rata 89,24 dengan standar deviasi 9,02. Uji statistik Wilcoxon didapatkan nilai $p$-value $0,000(\mathrm{p}<0,05)$ yang berarti ada pengaruh penyuluhan kesehatan terhadap pengetahuan tentang keputihan pada remaja putri di SMA Negeri 1 Talang Kelapa Banyuasin. Diharapkan kepada SMA Negeri I Talang Kelapa Banyuasin untuk mengadakan progam penyuluhan kesehatan bekerja sama dengan pihak puskesmas setempat dalam rangka memberikan informasi kesehatan reproduksi remaja.
\end{abstract}

Kata Kunci : Pendidikan Kesehatan, Pengetahuan, Keputihan, Remaja

Referensi : 30 (2009-2019)

\begin{abstract}
Leucorrhoea can be considered as one of the body's alarms, especially for reproductive problems,because reproductive health is an important component for women's health. Leucorrhoea is also often considered as an ordinary female problem, although it is often experienced by women. Adolescent reproductive health is a healthy condition that concerns the reproductive systems, functions and processes possessed by adolescents. Therefore, adolescents often lack information about reproductive health, therefore it is important to provide health education to teenage girl. The aim of this research was to determine the effect of health knowledge about leucorrhoea for teenage girls at SMA Negeri 1 Talang Kelapa Banyuasin. The design of this research used pre-experimental, that is one group pretest posttest. The sample of this research was 33 teenage girls in class $\mathrm{X}$. The sampling technique used a random sampling technique, that is systematic random sampling. The instrument of this research was a questionnaire. This research was conducted on November 1-14, 2019. The results of the research on the knowledge of teenage girl before give health education were carried out by an average value was 51.82 and standard deviation was 4.11. The knowledge of teenage girl after give health education with average score was 89.24 and standard deviation was 9.02. The statistical Wilcoxontest obtained a $p$ value was $0.000(\mathrm{p}<0.05)$, it means that there was an effect of health education about leucorrhea for teenage girl at SMA Negeri 1 Talang Kelapa Banyuasin. It is hoped that SMA Negeri I Talang Kelapa Banyuasin will hold a health education program in collaboration with the local health center in order to provide information on adolescent reproductive health.
\end{abstract}

Keywords : Health Education, Knowledge, Leucorrhoea, Teenage girl

References : 30 (2009-2019)

Volume X No. 2 Desember 2020 Hal - 133 


\section{PENDAHULUAN}

Menurut WHO (World Health Organizations) kesehatan reproduksi merupakan suatu keadaan fisik, mental dan sosial yang utuh, bukan hanya bebas dari penyakit kecacatan dalam segala aspek yang berhubungan dengan sistem reproduksi, fungsi serta prosesnya atau suatu keadaan dimana manusia dapat menikmati kehidupan seksualnya serta mampu menjalankan fungsi dan proses reproduksinya secara sehat dan aman (Rahmawati, 2015).

Kesehatan reproduksi merupakan komponen penting bagi kesehatann wanita. Keadaan penyakit pada wanita lebih banyak dihubungkan dengan fungsi dan kemampuan bereproduksi serta tekanan sosial pada wanita karena masalah gender. Wanita memiliki kebutuhan kesehatan khusus yang berhubungan dengan fungsi seksual dan reproduksi. Wanita mempunyai sistem reproduksi yang sensitif terhadap kerusakan yang dapat terjadi disfungsi atau penyakit (Kusmiran, 2012).

Kesehatan reproduksi remaja adalah suatu kondisi sehat yang menyangkut sistem, fungsi, dan proses reproduksi yang dimiliki oleh remaja. Pengertian sehat disini tidak semata-mata berarti bebas penyakit atau bebas dari kecacatan, tapi juga sehat secara mental serta sosial kultural (Indriyani \& Asmuji, 2014).

Menurut WHO masa remaja merupakan masa peralihan dari masa kanak- kanak menuju masa dewasa, dimana pada masa itu terjadi pertumbuhan yang pesat termasuk fungsi reproduksi sehingga memengaruhi terjadinya perubahan-perubahan perkembangan, baik fisik, mental, maupun peran social (Kumalasari \& Andhyantoro, 2012)
Remaja seringkali kekurangan informasi mengenai kesehatan reproduksi, keterampilan menegosiasikan hubungan seksual, dan akses terhadap pelayanan kesehatan reproduksi yang terjangkau serta terjamin kerahasiaannya. Keprihatinan akan jaminan kerahasisaan (privacy) atau kemampuan membayar dan kenyataan atau persepsi remaja terhadap sikap tidak senang yang ditunjukkan oleh pihak petugas kesehatan, semakin membatasi akses pelayanan lebih jauh meski pelayanan itu ada (Purwoastuti \& Walyani, 2015).

Keputihan merupakan keluarnya cairan selain darah dari liang vagina diluar kebiasaan, baik berbau ataupun tidak, serta disertai gatal setempat. Keputihan yang abnormal bisa disebabkan oleh infeksi atau peradangan yang terjadi karena mencuci vagina dengan air kotor, pemeriksaan dalam yang tidak benar, pemakaian pembilas vagina yang berlebihan, pemeriksaan yang tidak hygienis, dan adanya benda asing dalam vagina (Kusmiran, 2012).

Keputihan kerap di anggap sebagai masalah kewanitaan yang biasa-biasa saja dan sering dialami oleh wanita. Jika memerhatikan keputihan terjadi ketika merasa lelah atau stress. Keputihan dapat di anggap sebagai salah satu alarm tubuh terutama untuk masalah reproduksi. Jika kita melihat keputihan tidak berupa lendir yang berwarna bening, segera koreksi kembali gaya hidup kita. Para wanita disarankan untuk tidak menganggap remeh atau biasa adanya pengeluaran cairan keputihan sehingga dianjurkan untuk pemeriksaan khusus atau rutin sehingga dapat menetapkan secara dini penyebab keputihan (Manuaba, dkk. 2009).

Fakor-faktor yang memicu berkembangnya keputihan antara lain 
karena pengetahuan yang rendah, apalagi remaja yang secara biologis serviknya belum matang, karena berada dalam masa peralihan, maka pada remaja sering ditemukan masalah-masalah yang berkaitan erat dengan tumbuh kembang tubuhnya. Terutama dalam hal ini adalah organ reproduksi yang memberi dampak besar bagi kehidupan remaja dimasa datang. Terlebih pada remaja putri yang memang diciptakan Tuhan Yang Maha Esa dengan bentuk dan fungsi tubuh yang sangat istimewa dan juga sangat rentan terhadap gangguan dari luar, dalam hal ini infeksi saluran reproduksi dengan gejala yang umum adalah keputihan (Dewi, 2014).

Data kependudukan kabupaten Banyuasin tahun 2017 berdasarkan kelompok umur memiliki remaja putri yang berumur 10-14 tahun berjumlah 36.404 jiwa (4,52\%), remaja putri yang berumur 15-19 tahun berjumlah 38.428 jiwa $(4,77 \%)$ dan remaja putri yang berumur 20-24 tahun berjumlah 35.050 jiwa (4,35\%) (Profil Perkembangan kependudukan Kabupaten Banyuasin, 2017).

Penelitian yang dilakukan oleh Fauziah (2015) yang berjudul pengaruh penyuluhan tentang keputihan terhadap perilaku pencegahan keputihan pada siswi kelas X di SMA Negeri I Pundong Bantul Yogyakarta. Menunjukkan ada pengaruh penyuluhan keputihan terhadap perilaku pencegahan keputihan dengan p-value 0,000 . Hal ini membuktikan penyuluhan tentang keputihan dapat meningkatkan perilaku siswi dalam mencegah keputihan.

Penelitian yang dilakukan oleh Irnawati, dkk (2016) yang berjudul perbedaan tingkat pengetahuan perawatan keputihan pra training dan post training pada siswi SMP Negeri 2 Jaken kabupaten
Pati. Menunjukan terdapat perbedaan tingkat pengetahuan perawatan keputihan pra training dan post training dengan nilai $p$ - value 0,000. Hal ini mengambarkan bahwa pendidikan kesehatan mampu meningkatkan pengetahuan.

Penelitian yang dilakukan oleh Yulifitria (2017) tentang pengaruh pendidikan kesehatan dalam meningkatkan pengetahuan tentang pencegahan keputihan patologis pada mahasiswi kebidanan Jakarta, menunjukan ada pengaruh pendidikan kesehatan dalam meningkatkan pengetahuan tentang pencegahan keputihan patologis dengan dengan nilai $p$ value 0,000 . Hal ini menunjukan ada pengaruh pendidikan kesehatan dalam meningkatkan pengetahuan tentang pencegahan keputihan patologis pada mahasiswi.

Pendidikan kesehatan adalah suatu penerapan konsep pedidikan dalam bidang kesehatan. Dilihat dari segi pendidikan, pendidikan kesehatan adalah suatu pedagogic praktis atau praktik kesehatan. Oleh sebab itu, konsep pendidikan kesehatan adalah konsep pendidikan yang diaplikasikan pada bidang kesehatan (Notoatmodjo, 2012).

Berdasarkan studi pendahuluan ke SMA Negeri 1 Talang Kelapa Banyuasin belum pernah dilakukan pendidikan kesehatan mengenai keputihan dari 5 siswi remaja putri yang peneliti lakukan wawancara ada 3 yang tidak mengetahui sama sekali tentang keputihan dan 2 diantaranya hanya dapat menjelaskan tentang keputihan dengan bahasa awam saja. SMA Negeri 1 Talang Kelapa Banyuasin merupakan salah satu sekolah yang berada di kabupaten Banyuasin. SMA Negeri 1 Talang Kelapa Banyuasin terdapat 24 kelas yang terdiri dari kelas $\mathrm{X}$ sebanyak 8 kelas dengan jumlah remaja putri 210 
orang, kelas XI sebanyak 8 kelas dengan jumlah remaja putri 192 orang dan kelas XII sebanyak 8 kelas dengan jumlah remaja putri 184 orang sehingga jumlah total remaja putri adalah 586 orang remaja putri. Peneliti akan melakukan penelitian pada kelas X saja dikarenakan mereka belum mendapatkan mata pelajaran tentang kesehatan reproduksi, sedangkan kelas XI dan XII telah mendapatkan mata pelajaran kesehatan reproduksi sesuai dengan kurikulum yang berlaku.

Terkait dengan kenyataan adanya pengetahuan yang belum dimiliki oleh para siswa SMA Negeri 1 Talang Kelapa Banyuasin tentang keputihan, maka penelitian ini menjadi perlu untuk dilakukan.

\section{METODE PENELITIAN}

Penelitian ini menggunakan desain pre eksperimen dengan pendekatan one group pretest posttest. Variable dalam penelitian ini adalah pengetahuan remaja sebelum dan sesudah dilakukan pendidikan kesehatan tentang keputihan. Sampel dalam penelitian ini adalah remaja putri kelas $\mathrm{X}$ di SMA Negeri 1 Talang Kelapa Banyuasin. Teknik pengambilan sampel yang digunakan dengan teknik random sampling yaitu systematic random sampling dengan jumlah sampel sebanyak 33 responden. Tehnik Pengumpulan data menggunakan kuesioner. Tehnik dianalisa data dilakukan secara univariat dan bivariat dengan menggunakan uji nonparametrik.

\section{HASIL DAN PEMBAHASAN}

\section{a. Pengetahuan remaja putri sebelum diberikan penyuluhan Kesehatan}

Tabel 3.1

Distribusi Frekuensi Pengetahuan Remaja Putri Sebelum Penyuluhan Kesehatan di SMA Negeri 1 Talang Kelapa Banyuasin Tahun 2019

\begin{tabular}{|l|l|l|l|l|c|c|}
\hline \multicolumn{1}{|c|}{ Variabel } & Mean & Median & $\begin{array}{c}\text { Min- } \\
\text { max }\end{array}$ & SD & $\begin{array}{c}\mathbf{9 5 \%} \\
\text { Lower- } \\
\text { Upper }\end{array}$ & $\begin{array}{c}\mathbf{P} \\
\text { Value }\end{array}$ \\
\hline $\begin{array}{l}\text { Pengetahuan } \\
\text { responden } \\
\text { sebelum } \\
\text { penyuluhan } \\
\text { kesehatan }\end{array}$ & 51,82 & 50,00 & $40-60$ & 4,11 & $\begin{array}{c}50,36- \\
53,28\end{array}$ & 0,000 \\
\hline
\end{tabular}

Hasil penelitian diperoleh hasil nilai ratarata 51,82 dan hasil nilai tengah adalah 50,00, dengan tingkat kepercayaan 95\% Lower bound 50,36 dan upper bound 53,28. Sedangkan nilai remaja putri terkecil untuk pengetahuan sebelum penyuluhan kesehatan adalah 40 dan nilai tertingginya adalah 60 dengan standar deviasi 4,11 maka didapatkan hasil $p$ value $0,000(\mathrm{p}<0,05)$.

Pengetahuan merupakan hasil dari tahu dan ini terjadi setelah orang melakukan pengindraan terhadap suatu objek $\mathrm{t}$ ertentu. Pengindraan terjadi melalui pancaindra manusia, yakni indra penglihatan, pendengaran, penciuman, rasa dan raba. Sebagian besar pengetahuan manusia diperoleh melalui mata dan telinga. Pengetahuan atau ranah kognitif merupakan domain yang sangat penting dalam membentuk tindakan seseorang (overt behavior) (Notoatmodjo, 2012). Dalam kamus besar bahasa Indonesia, pengetahuan adalah suatu yang diketahui berkaitan dengan proses pembelajaran (Budiman \& Riyanto, 2013).

Penyuluhan kesehatan diperlukan sebagai upaya meningkatkan pengetahuan dan kesadaran, di samping pengetahuan sikap dan perbuatan. Oleh karena itu, tentu diperlukan upaya penyediaan dan penyampaian informasi, yang merupakan bidang garapan penyuluhan kesehatan. Makna asli penyuluhan adalah 
pemberian penerangan dan informasi (Maulana, 2014).

Menurut Steuart (1968), pendidikan kesehatan adalah merupakan upaya komponen program kesehatan (kedokteran) yang isinya perencanaan untuk perubahan perilaku individu, kelompok dan masyarakat sehubungan dengan pencegahan penyakit, penyembuhan penyakit dan pemulihan kesehatan (Fitriani, 2011).

Fakor-faktor yang memicu berkembangnya keputihan antara lain karena pengetahuan yang rendah, apalagi remaja yang secara biologis serviknya belum matang, karena berada dalam masa peralihan, maka pada remaja sering ditemukan masalah-masalah yang berkaitan erat dengan tumbuh kembang tubuhnya. Dalam hal ini infeksi saluran reproduksi dengan gejala yang umum adalah keputihan. Remaja putri pada umumnya malu untuk menceritakan masalah yang berkaitan dengan organ kelamin apalagi untuk memeriksakannya (Kusmiran, 2012).

Hasil penelitian Sekar, dkk (2016) yang berjudul pengaruh pendidikan kesehatan tentang vulva hygiene terhadap pengetahuan, sikap dan praktik remaja putri yang mengalami keputihan di Pondok Pesantren Al-Izzah Demak. Didapatkan skor tingkat pengetahuan remaja putri sebelum dilakukan pendidikan kesehatan rata-rata 73,73 dengan standar deviasi 1,142 dan skor tingkat pengetahuan minimum 50,00 dan maximum 93,00.

Pada hasil penelitian Arianti (2017) yang meneliti pengaruh pengetahuan remaja tentang vulva hygiene terhadap perubahan perilaku pencegahan keputihan patologi pada siswi kelas $\mathrm{X}$ di SMA Muhammadiyah 3 Yogyakarta, didapatkan bahwa dari 90 responden sebelum penyuluhan dilakukan sebagian besar siswi berpengetahuan cukup sebanyak 52 orang $(57,8 \%)$. Hal ini menunjukan bahwa siswi yang berpengetahuan cukup disebabkan karena belum mendapatkan informasi pendidikan kesehatan tentang vulva hygiene terkait perilaku pencegahan keputihan patologis.

Hasil penelitian Andriyani (2018) tentang pengaruh pendidikan kesehatan genital hygiene terhadap tingkat pengetahuan dalam pencegahan keputihan pada remaja siswi di SMA Muhammadiyah Pakem Sleman Yogyakarta, menunjukan bahwa dari 42 responden sebelum penyuluhan dilakukan sebagian besar siswi mempunyai pengetahuan cukup sebanyak 32 orang $(76,20 \%)$. Hal ini juga dikarenakan belum mendapatkan informasi pendidikan kesehatan tentang genital hygiene dalam pencegahan keputihan.

Hasil penelitian Ariyanti, dkk (2019) tentang perbedaan pengetahuan remaja putri sebelum dan sesudah diberikan penyuluhan tentang flour albus di SMP Negeri 3 Penebel, pada pengetahuan sebelum diberikan penyuluhan tentang flour albus sebagian besar responden mempunyai tingkat pengetahuan dalam kategori baik $(70 \%)$ dengan nilai ratarata 11,56. Hal ini menunjukan banyaknya responden yang dapat menjawab dengan tepat tentang keputihan.

Hasil penelitian Meliyanti dan Shyffaviana (2019) tentang tingkat pengetahuan remaja putri sebelum dan sesudah dilakukan penyuluhan tentang keputihan di SMP Muhammadiyah 6 kota Bandung, menunjukan bahwa pengetahuan remaja putri sebelum dilakukan penyuluhan tentang keputihan sebagian besar dengan pengetahuan cukup sebanyak 40 responden $(61,5 \%)$ dari 65 responden. Kurangnya pengetahuan remaja putri tentang keputihan tersebut karena kurangnya informasi tentang keputihan dan responden kurang mencari informasi mengenai keputihan.

Berdasarkan hasil penelitian dan teori diatas peneliti berpendapat bahwa pengetahuan tentang keputihan pada remaja putri di SMA Negeri 1 Talang Kelapa Banyuasin masih rendah ataupun kurang. Hasil ini sangat mungkin terjadi karena belum mengetahui definisi, jenis-jenis, penyebab, tanda dan gejala, serta pencegahan dari keputihan serta belum didapatnya mata pelajaran yang memuat materi tentang kesehatan reproduksi. Remaja putri tersebut hanya sekedar mengetahui bahwa keputihan atau flour albus adalah cairan encer seperti jel yang keluar dari vagina tidak lebih dari itu. Pengetahuan tentang keputihan atau 
flour albus tentunya perlu diketahui oleh remaja putri sebab dengan mengetahui keputihan maka mereka dapat menangani keputihan yang sering kali dialami oleh wanita pada umumnya, agar tidak menimbulkan masalah yang lebih fatal seperti menyebabkan penyakit keganasan pada organ reproduksi. Sangat penting dilakukan penyuluhan kesehatan tentang keputihan pada remaja putri karena akan menambah pengetahuan tentang keputihan.

\section{b. Pengetahuan Remaja Putri Sesudah Penyuluhan Kesehatan}

Tabel 3.2

Distribusi Frekuensi Pengetahuan Remaja Putri Sesudah Penyuluhan Kesehatan di SMA Negeri 1 Talang Kelapa Banyuasin Tahun 2019

\begin{tabular}{|c|c|c|c|c|c|c|}
\hline Variabel & Mean & Median & $\begin{array}{l}\text { Min- } \\
\text { max }\end{array}$ & SD & $\begin{array}{c}95 \% \\
\text { Lower- } \\
\text { Upper }\end{array}$ & $\begin{array}{c}\mathrm{P} \\
\text { Value }\end{array}$ \\
\hline $\begin{array}{l}\text { Pengetahuan } \\
\text { responden } \\
\text { sesudah } \\
\text { penyuluhan } \\
\text { kesehatan }\end{array}$ & 89,24 & 90,00 & $55-95$ & 9,02 & $\begin{array}{l}86,04- \\
92,44\end{array}$ & 0,000 \\
\hline
\end{tabular}

Hasil penelitian didapatkan hasil nilai ratarata 89,24 dan hasil nilai tengah adalah 90,00 dengan tingkat kepercayaan $95 \%$ Lower bound 86,04 dan Upper bound 92,44. Sedangkan nilai terkecil untuk pengetahuan sesudah penyuluhan kesehatan adalah 55 dan nilai tertinggi nya adalah 95 dengan standar deviasi 9,02 maka didapatkan hasil $p$ value $0,000(\mathrm{p}<0,05)$.

Menurut Mubarak (2012), terdapat tujuh faktor yang memengaruhi pengetahuan seseorang, yaitu pendidikan, pekerjaan, umur, minat, pengalaman, kebudayaan lingkungan sekitar, dan informasi. Faktor-faktor yang mempengaruhi pengetahuan adalah pendidikan, informasi/media massa, sosial budaya, lingkungan, pengalaman, dan umur. Pengukuran pengetahuan dapat dilakukan dengan wawancara atau angket yang menanyakan tentang isi materi yang ingin diukur dari subjek penelitian atau respon (Budiman \& Riyanto, 2013).
Pendidikan kesehatan memotivasi orang untuk mendapatkan informasi tersebut, demi menjaga agar individu lebih sehat dengan cara menghindari tindakan yang membahayakan dan dengan membentuk kebiasaan yang menguntungkan (Novita, 2011). Pendidikan kesehatan adalah proses membuat orang mampu meningkatkan dan memperbaiki kesehatan mereka (Mubarak, 2012).

Hasil penelitian Sekar, dkk (2016) yang berjudul pengaruh pendidikan kesehatan tentang vulva hygiene terhadap pengetahuan, sikap dan praktik remaja putri yang mengalami keputihan di Pondok Pesantren Al-Izzah Demak. Didapatkan skor tingkat pengetahuan remaja putri sesudah dilakukan pendidikan kesehatan rata-rata 93,35 dengan standar deviasi 0,629 dan skor tingkat pengetahuan minimum 81,25 dan maximum 100.

Hasil penelitian Arianti (2017) yang meneliti pengaruh pengetahuan remaja tentang vulva hygiene terhadap perubahan perilaku pencegahan keputihan patologi pada siswi kelas $\mathrm{X}$ di SMA Muhammadiyah 3 Yogyakarta, didapatkan bahwa dari 90 responden sesudah penyuluhan dilakukan sebagian besar siswi dengan pengetahuan baik 77 responden $(85,6 \%)$. Hal ini menunjukan ada perubahan perilaku remaja dalam pencegahan keputihan.

Hasil penelitian Andriyani (2018) tentang pengaruh pendidikan kesehatan genital hygiene terhadap tingkat pengetahuan dalam pencegahan keputihan pada remaja siswi di SMA Muhammadiyah Pakem Sleman Yogyakarta, didapatkan dari 42 responden sesudah penyuluhan dilakukan sebagian besar siswi mempunyai pengetahuan baik sebanyak 42 responden (100\%). Hal ini disebabkan terdapat peningkatan pengetahuan dari proses pemberian pendidikan kesehatan.

Hasil penelitian Ariyanti, dkk (2019) tentang perbedaan pengetahuan remaja putri sebelum dan sesudah diberikan penyuluhan tentang flour albus di SMP Negeri 3 Penebel, pada pengetahuan sesudah diberikan penyuluhan tentang flour albus didapatkan sebagian besar responden mempunyai tingkat pengetahuan dalam kategori baik (96\%) dengan 
nilai rata-rata 14,23 . Hal ini menunjukan adanya peningkatan pengetahuan remaja putri tentang flour albus sebesar 2,67.

Hasil penelitian Meliyanti dan Shyffaviana (2019) tentang tingkat pengetahuan remaja putri sebelum dan sesudah dilakukan penyuluhan tentang keputihan di SMP Muhammadiyah 6 kota Bandung, didapatkan pengetahuan remaja putri sesudah dilakukan penyuluhan tentang keputihan sebagian besar dengan pengetahuan baik sebanyak 59 responden $(90,8 \%)$ dari 65 responden.

Berdasarkan hasil penelitian dan teori yang ada, peneliti berpendapat bahwa pengetahuan remaja putri tentang keputihan meningkat dikarenakan oleh factor-faktor dimana penyuluhan kesehatan dilakukan melalui metode ceramah dan diskusi dengan menggunakan alat bantu/media leaflet dan poster yang dibagikan pada remaja putri, serta penyampaian dengan audio visual LCD saat penyuluhan berlangsung yang mempermudah remaja putri untuk lebih memahami materi yang diberikan dan adanya rasa ingin tau yang besar oleh remaja putri sehingga remaja putri mampu menangkap informasi yang diberikan oleh peneliti dengan baik serta didalam pelaksanaan penyuluhan kesehatan terdapat umpan balik atau feedback berupa pertanyaan dari responden sehingga remaja putri mengetahui secara luas tentang keputihan. Penyuluhan tersebut dapat membantu mengingat apa yang disampaikan oleh peneliti sehingga sama dengan pertanyaan yang ada di kuesiner

\section{c. Pengaruh Penyuluhan Kesehatan Terhadap Pengetahuan}

Tabel 3.3

Pengaruh Penyuluhan Kesehatan Tentang Keputihan di SMA Negeri 1 Talang Kelapa Banyuasin Tahun 2019

\begin{tabular}{|c|c|c|c|c|c|c|}
\hline \multicolumn{1}{|c|}{ Variabel } & Mean & Median & SD & Min & Max & $\begin{array}{c}\text { P } \\
\text { Value }\end{array}$ \\
\cline { 1 - 6 } $\begin{array}{l}\text { Pengetahuan } \\
\text { Sebelum }\end{array}$ & 51,82 & 50,00 & 4,11 & 40 & 60 & \multirow{2}{*}{0,000} \\
\cline { 2 - 6 } $\begin{array}{l}\text { Pengetahuan } \\
\text { Sesudah }\end{array}$ & 89,24 & 90,00 & 9,02 & 55 & 95 & \\
\cline { 2 - 6 } & & & &
\end{tabular}

Tabel 3.4

Perbandingan Pengetahuan Remaja Putri Sebelum dan Sesudah Penyuluhan Kesehatan di SMA Negeri 1 Talang Kelapa Banyuasin Tahun 2019

\begin{tabular}{|c|c|c|c|c|c|c|}
\hline $\begin{array}{c}\text { Varia } \\
\text { bel }\end{array}$ & Rank & $\mathbf{N}$ & $\begin{array}{l}\text { Mean } \\
\text { Rank }\end{array}$ & $\begin{array}{c}\text { Sum } \\
\text { of } \\
\text { Rank }\end{array}$ & $\mathrm{Z}$ & $\begin{array}{c}P \\
\text { Value }\end{array}$ \\
\hline \multirow{4}{*}{$\begin{array}{l}\text { Penget } \\
\text { ahuan } \\
\text { sebelu } \\
\mathrm{m} \\
\text { penyul } \\
\text { uhan- } \\
\text { Penget } \\
\text { ahuan } \\
\text { sesuda } \\
\text { h } \\
\text { penyul } \\
\text { uhan }\end{array}$} & $\begin{array}{l}\text { Negati } \\
\text { fRank }\end{array}$ & 0 & 0,00 & 0,00 & \multirow{4}{*}{$-4,900$} & \multirow{4}{*}{0,000} \\
\hline & $\begin{array}{l}\text { Positif } \\
\text { Rank }\end{array}$ & 31 & 16,00 & 496,00 & & \\
\hline & Ties & 2 & & & & \\
\hline & Total & 33 & & & & \\
\hline
\end{tabular}

Hasil penelitian didapatkan rata-rata nilai pengetahuan tentang keputihan sebelum dilakukan penyuluhan kesehatan adalah 51,82 , nilai tengahnya 50,00 , nilai terendah 40 dan nilai tertinggi 60 dengan standar deviasi 4,11. Sedangkan rata-rata pengetahuan remaja putri tentang keputihan sesudah dilakukan penyuluhan kesehatan adalah 89,24 , nilai tengahnya 90,00 , nilai terendahnya 55 dan nilai tertingginya 95 dengan standar deviasi 9,02. Hasil uji statistik dengan uji wilcoson didapatkan nilai $p$ value 0,000 . Hasil ini menyatakan adanya pengaruh penyuluhan kesehatan terhadap pengetahuan tentang keputihan pada remaja putri di SMA Negeri 1 Talang Kelapa Banyuasin.

Hasil perbandingan sebelum dan sesudah pemberian penyuluhan kesehatan menunjukkan bahwa terdapat 2 responden dengan pengetahuan yang tetap sebelum dan sesudah penyuluhan dan 31 orang dengan hasil pengetahuan setelah penyuluhan lebih tinggi dari pada sebelum diberikan penyuluhan serta tidak ada responden dengan hasil pengetahuan setelah penyuluhan lebih rendah dari pada sebelum penyuluhan diperoleh nilai signifikan $p$ value $0,000(\mathrm{p}<0,05)$ dengan demikian dapat disimpulkan bahwa terdapat perbedaan yang bermakna antara pengetahuan sebelum dan sesudah diberikan penyuluhan kesehatan tentang keputihan dan penyuluhan kesehatan 
sangat efektif untuk meningkatkan pengetahuan remaja putri tentang keputihan.

Penyuluhan kesehatan merupakan kegiatan pendidikan kesehatan, yang dilakukan dengan menyebarkan pesan, menanamkan keyakinan sehingga masyarakat tidak saja, tahu, dan mengerti, tetapi juga mau dan dapat melakukan anjuran yang berhubungan dengan kesehatan. Penyuluhan kesehatan dalam promosi kesehatan diperlukan sebagai upaya meningkatkan pengetahuan dan kesadaran, di samping pengetahuan sikap dan perbuatan. Oleh karena itu, tentu diperlukan upaya penyediaan dan penyampaian informasi, yang merupakan bidang garapan penyuluhan kesehatan. Makna asli penyuluhan adalah pemberian penerangan dan informasi (Maulana, 2014).

Menurut Skinner, bila seseorang mampu menjawab mengenai materi tersebut baik secara lisan maupun tulisan, maka dikatakan seseorang tersebut mengetahui bidang tersebut. Sekumpulan jawaban yang diberikan tersebut dinamakan pengetahuan (Budiman \& Riyanto, 2013).

Menurut Joint Commission On Health Education, USA (1973), pendidikan kesehatan adalah kegiatan-kegiatan yang ditujukan untuk meningkatkan kemampuan orang dan membuat keputusan yang tepat sehubungan dengan pemeliharaan kesehatan (Fitriani, 2011).

Menurut Lawrence Green (1972), pendidikan kesehatan adalah istilah yang diterapkan pada pengguna proses pendidik secara terencana untuk mencapai tujuan kesehatan yang meliputi beberapa kombinasi dan kesempatan pembelajaran (Mubarak, 2012).

Hasil penelitian Sekar, dkk (2016) yang berjudul pengaruh pendidikan kesehatan tentang vulva hygiene terhadap pengetahuan, sikap dan praktik remaja putri yang mengalami keputihan di Pondok Pesantren Al-Izzah Demak. Hasil uji statistik dengan paired t-test didapatkan $p$-value 0,000. Ini menunjukan ada pengaruh pendidikan kesehatan tentang vulva hygiene terhadap pengetahuan, sikap dan praktik remaja putri yang mengalami keputihan.
Hal ini membuktikan bahwa pendidikan kesehatan tentang vulva hygiene dapat meningkatkan pengetahuan, sikap dan praktik remaja putri pada saat mengalami keputihan.

Pada hasil penelitian Arianti (2017) yang meneliti pengaruh pengetahuan remaja tentang vulva hygiene terhadap perubahan perilaku pencegahan keputihan patologi pada siswi kelas $X$ di SMA Muhammadiyah 3 Yogyakarta, menunjukan bahwa hasil uji statistik wilcoxon dengan nilai $p$-value 0,000 yang berarti ada pengaruh pengetahuan remaja tentang perilaku vulva hygiene terhadap perubahan perilaku pencegahan keputihan patologi pada siswi.

Hasil penelitian Andriyani (2018) tentang pengaruh pendidikan kesehatan genital hygiene terhadap tingkat pengetahuan dalam pencegahan keputihan pada remaja siswi di SMA Muhammadiyah Pakem Sleman Yogyakarta, hasil uji statistik wilcoxon didapatkan nilai $p$-value 0,000 yang berarti ada pengaruh pendidikan kesehatan genital hygiene terhadap tingkat pengetahuan dalam pencegahan keputihan pada remaja siswi.

Hasil penelitian Ariyanti, dkk (2019) tentang perbedaan pengetahuan remaja putri sebelum dan sesudah diberikan penyuluhan tentang flour albus di SMP Negeri 3 Penebel, menunjukan hasil uji statistik wilcoxon dengan nilai $p$-value 0,000 yang berarti ada perbedaan yang signifikan antara tingkat pengetahuan remaja sebelum dan sesudah diberikan penyuluhan sehingga metode penyuluhan dapat dikatakan efektif dalam meningkatkan pengetahuan remaja putri tentang flour albus.

Hasil penelitian Meliyanti dan Shyffaviana (2019) tentang tingkat pengetahuan remaja putri sebelum dan sesudah dilakukan penyuluhan tentang keputihan di SMP Muhammadiyah 6 kota Bandung, menunjukan bahwa pada hasil rata-rata nilai yang didapat sesudah diberikan intervensi lebih besar dari nilai sebelum diberikan intervensi. Hal ini menunjukan bahwa terdapat peningkatan pengetahuan antara sebelum dan sesudah intervensi diberikan.

Berdasarkan hasil penelitian dan teori diatas, dapat dinyatakan bahwa penyuluhan memiliki pengaruh yang signifikan terhadap 
pengetahuan remaja putri di SMA Negeri 1 Talang Kelapa Banyuasin. Penyuluhan yang dilakukan dengan metode ceramah dan diskusi melalui alat bantu/media leaflet dan poster serta penyampaian materi dengan audio visual LCD pelaksanaannya terdapat umpan balik atau feedback berupa pertanyaan dari responden. Kegiatan penyuluhan ini dapat menunjang kegiatan belajar-mengajar di sekolah dan dapat dikembangkan sehingga menjadi bagian dari kegiatan rutin pihak sekolah bekerja sama dengan puskesmas setempat untuk mengadakan penyuluhan kesehatan reproduksi remaja serta adanya kurikulum memuat mata pelajaran yang didalamnya terdapat materi tentang kesehatan reproduksi remaja yang salah satunya gangguannya adalah keputihan.

\section{SIMPULAN DAN SARAN}

Pengetahuan remaja putri sebelum dilakukan penyuluhan kesehatan tentang keputihan di SMA Negeri 1 Talang Kelapa Banyuasi adalah nilai rata-rata 51,82 , hasil nilai tengah 50,00, dengan tingkat kepercayaan 95\% Lower bound 50,36 dan Upper bound 53,28. Nilai terendah responden 40 sedangkan nilai tertinggi responden 60 dengan standar deviasi 4,11. Pengetahuan remaja putri sesudah dilakukan penyuluhan kesehatan tentang keputihan pada di SMA Negeri 1 Talang Kelapa Banyuasin adalah nila rata-rata 89,24 , hasil nilai tengah adalah 90,00, dengan tingkat kepercayaan 95\% Lower bound 86,04 dan Upper bound 92,44. Nilai terendah responden 55 sedangkan nilai tertinggi responden 95 dengan standar deviasi 9,02. Ada pengaruh penyuluhan kesehatan terhadap pengetahuan tentang keputihan pada remaja putri di SMA Negeri 1 Talang Kelapa Banyuasin yaitu dengan nilai $p$ value $0,000 \quad(\mathrm{p}<0,05)$. Diharapkan adanya progam penyuluhan kesehatan untuk meningkatkan pengetahuan remaja putri melalui kerja sama dengan pihak puskesmas setempat dalam rangka memberikan informasi kesehatan reproduksi remaja serta pemberian informasi melalui media cetak dan elektronik untuk peningkatan pengetahuan remaja putri dalam upaya peningkatan kesehatan reproduksi remaja putri di SMA Negeri 1 Talang Kelapa Banyuasin.

\section{DAFTAR PUSTAKA}

Andriyani S. 2018. Pengaruh pendidikan kesehatan genital hygiene terhadap tingkat pengetahuan dalam pencegahan keputihan pada remaja siswi di SMA Muhammadiyah Pakem Sleman Yogyakarta. Naskah Publikasi. Program Studi Kebidanan Program Sarjana Terapan Fakultas Ilmu Kesehatan Universitas Aisyiyah Yogyakarta.(http://digilib2.unisa yogya.ac.id/xmlui/bitstream/han dle/123456789/1256/NASKAH \%20PUBLIKASI\%20SELVI\%2 0ANDRIYANI.pdf?sequence $=1$ \&isAllowed=y) diakses: 15 Juli 2020 pukul: 09.56

Arianti R. 2017. Pengaruh Pengetahuan . Remaja Tentang Vulva Hygiene Terhadap Perubahan Perilaku Pencegahan Keputihan Patologi Pada Siswi Kelas X Di SMA Muhammadiyah 3 Yogyakarta. Naskah Publikasi. Program Studi Bidan Pendidik Jenjang Diploma IV Universitas Aisyiyah Yogyakarta(http://digilib.unisay ogya.ac.id/3042/1/Naskah\%20fi x.pdf) diakses: 15 Juli 2020 pukul: 09.59

Ariyanti KS, dkk. 2019. Perbed Pengetahuan Remaja Putri Sebelum Dan Sesudah Diberikan Penyuluhan Tentang Flour Albus Di SMP Negeri 3 Penebel Jurnal medika Usada volume 2 No.1 (file:///C:/Users/acer/Downloads /32-Article\%20Text-145-3-1020190402.pdf) diakses: 14 Juli 2020 pukul: 12.5 
Aulia. 2012. Serangan Penyakit-penyakit Khas Wanita Paling Sering Terjadi. Jogjakarta: Buku Biru.

Budiman \& Riyanto. A. 2013. Kapita Selekta Kuesioner Pengetahuan dan Sikap dalam Penelitian Kesehatan. Jakarta: Salemba Medika.

Fauziah N. 2015. Pengaruh Penyuluhan Tentang Keputihan Terhadap Perilaku Pencegahan Keputihan Pada Siswi Kelas X Di SMA Negeri I Pundong Bantul Yogyakarta. Naskah Publikasi. Program Studi Bidan Pendidik Jenjang Diploma IV Sekolah Tinggi Ilmu.Kesehatan Aisyiyah Yogyakarta(http://digilib.unisay ogya.ac.id/1887/1/Nur\%20Fauzi ah_201410104124_NASKAH\% 20PUBLIKASI.pdf) diakses: 20 Agustus 2019 pukul: 09.50

Fitriani, Sinta. 2011. Promosi Kesehatan. Yogyakarta: Graha Ilmu.

Indriyani D \& Asmuji. 2014. Buku Ajar. Maternitas: Upaya Promotif dan Preventif dalam Menurunkan Angka Kematian Ibu dan Bayi. Yogyakarta: Ar-Ruzz Media.

Irnawati Y, dkk. 2016. Perbedaan tingkat pengetahuan perawatan keputihan pra training dan post training pada siswi SMP Negeri 2 Jaken kabupaten Pati. Jurnal ilmu kebidanan dan kesehatan (Journal of midwifery science and health) Vol.7 No.2 Juli (https://scholar.google.com/citati ons?user=e8IoG9kAAAAJ\&hl= en\#d=gs_mdcitad\&u=\%2Fcitati ons\%3Fview_op\%3Dview_citati on\%26hl\%3Den\%26user3De8Io G9kAAAAJ\%26citation_for_vie w\%3De8IoG9kAAAAJ\%3Ad1g
kVwhDpl0C\%26tzom\%3D-420) diakses: 21 Agustus 2019 pukul: 10.09

Kumalasari \& Andyantoro. 2012. Kesehatan reproduksi untuk mahasiswa kebidanan \& keperawatan. Jakarta : Salemba Medika.

Kusmiran, Eny. 2012. Kesehatan Reproduksi Remaja dan Wanita. Jakarta: Salemba. Medika.

Manuaba, dkk. 2009. Memahami Kesehatan Reproduksi Wanita Edisi 2. Jakarta: . EGC.

Mardalis. 2014. Metodo Penelitian (Suatu.Pendekatan Proposal). Jakarta: Bumi. Aksara.

Maulana Dj Heri. 2014. Promosi kesehatan. Jakarta: Buku Kedokteran EGC.

Meliyanti, M \& Shyffaviana, B. 2019. Tingkat pengetahuan remaja putri sebelum dan sesudah dilakukan penyuluhan tentang keputihan di SMP Muhammadiyah $6 \quad$ kota Bandung. Jurnal Sehat Masada Volume XIII No.1 Januari .(file:///C:/Users/acer/Download s/73-Article\%20Text-104-1-1020190516.pdf) diakses: 14 Juli 2020 pukul: 12.49

Mubarak, Iqbal W. 2012. Promosi Kesehatan. Untuk Kebidanan. Jakarta: Salemba . Medika.

Mumpuni, Yekti \& Andang, Tantrini. 2013. 45 Penyakit Musuh Kaum Perempuan. Yogyakarta: Rapha Publishing.

Notoatmodjo, Soekidjo. 2012. Promosi Kesehatan Dan Perilaku 
Kesehatan. Jakarta: Rineka Cipta.

2012. Metodologi

Penelitian Kesehatan. Penerbit Rineka Cipta: . Jakarta.

Novita Nesi. 2011. Promosi kesehatan dalam pelayanan kebidanan. Jakarta: Salemba. Medika.

Nugroho. T \& Setiawan. A. 2010. Kesehatan. Wanita, Gender dan Permasalahannya. Yogyakarta: Nuha Medika.

Nurchasanah. 2009. Ensiklopedi Kesehatan Wanita. Yogyakarta: Familia.

Prayitno, Sunyoto. 2014. Buku Lengkap Kesehatan Organ Reproduksi Wanita. Jogjakarta: Saufa.

Purwoastuti, Endang \& Walyani, Siwi E. 2015. Panduan Materi Kesehatan Reproduksi dan Keluarga Berencana. Yogyakarta: Pustaka Baru Press.

Rahmawati, Iis. 2015. Buku Ajar Keperawatan Klinik VII (Sistem Reproduksi). Jakarta: TIM.

Sari, Wening, dkk. 2012. Panduan Lengkap Kesehatan Wanita. Jakarta: Penebar Plus.

Sekar P, dkk. 2016. Pengaruh Pendidikan Kesehatan Tentang Vulva Hygiene Terhadap Pengetahuan, Sikap Dan Praktik Remaja Putri Yang Mengalami Keputihan Di Pondok Pesantren Al-Izzah Demak. Jurnal Ilmu Keperawatan dan Kebidanan (file:///C:/Users/acer/Downloads /499-997-1-SM.pdf) diakses: 15 Juli 2020 pukul: 09.46
Simbangda Banyuasin. 2017. Profil Perkembangan Kependudukan Kabupaten Banyuasin. (http:simbangda.banyuasinkab.g o.id) diakses: 08 Agustus 2019 pukul: 11.10

Sugiyono. 2016. Metode Penelitian Kuantitaif, Kualitatif, dan $R \& D$. Bandung: Alfabeta.

Yulifitria F, 2017. Pengaruh Pendidikan Kesehatan Dalam Meningkatkan Pengetahun Tentang Pencegahan Keputihan Patologis. Jurnal bidan "Midwife Journal" Volume 3 No. 02 http://jurnal.ibijabar.org/wpcontent/uploads/2017/09/10FAUZIAH-YULFITRIA-poltekjkt-3.pdf) diakses: 07 Agustus 2019 pukul: 09.23 
